\title{
IMPLEMENTASI PENGUATAN PENDIDIKAN KARAKTER PADA MATERI RUANG LINGKUP BIOLOGI
}

\author{
Tiurlina Siregar $^{1)}$; Joko Waluyo ${ }^{2)}$; Subiyanto ${ }^{3)}$ \\ ${ }^{1)}$ Program Studi Magister Pendidikan IPA UNCEN; tiurlina.siregar@yahoo.com \\ ${ }^{2)}$ Balai Diklat Keagamaan Papua; j.waluyo20@yahoo.co.id \\ ${ }^{33}$ SMA Negeri 4 Jayapura; subiyantojpr@mail.com
}

\begin{abstract}
The purpose of this study was to determine the implementation of strengthening character education to increase learning outcomes in the material in the scope of biology. The method in this research is the furpossive sampling method and the data collection technique that be used is a questionnaire, which is a data collection technique that is done by giving a set of questions or written statements to the respondent. There is an effect of the implementation of strengthening character education on the learning outcomes of biology subject in class XI SMA Negeri 4 Jayapura City. This is based on the results of the simple regression test, it is obtained that $t$ count is greater than $t$ table (2.174> 1.960) and the significance is $0.031<0.05$ with the regression equation $Y=63.870+0.177 X 2$ with a contribution or relative contribution of $1.7 \%$, Increased mastery of the concept of space material the scope of biology is above 0.7, which means that students have mastery of concepts. The results of the calculation of the pretest and posttest values have an increase of 0.85 in the moderate category.
\end{abstract}

Key words: Implementation; Strengthening Character Education

\begin{abstract}
ABSTRAK
Tujuan dalam penelitian ini adalah untuk mengetahui implementasi penguatan pendidikan karakter terhadap peningkatan hasil belajar pada materi ruang lingkup biologi. Metode dalam penelitian ini adalah metode furpossive sampling dan teknik pengumpulan data yang digunakan berupa kuesioner (angket), yaitu teknik pengumpulan data yang dilakukan dengan cara memberi seperangkat pertanyaan atau pernyataan tertulis kepada responden. Terdapat pengaruh implementasi penguatan pendidikan karakter terhadap hasil belajar materi ruang lingkup biologi kelas XI SMA Negeri 4 Kota Jayapura. Hal ini berdasarkan hasil uji regresi sederhana diperoleh $t_{\text {hitung }}$ lebih besar dari $t_{\text {tabel }}(2,174>1,960)$ dan signifikansinya $0,031<0,05$ dengan persamaan regresi $\mathrm{Y}=63,870+0,177 \mathrm{X}_{2}$ dengan sumbangan atau kontribusi relatif sebesar $1,7 \%$, Peningkatan penguasaan konsep materi ruang lingkup biologi berada di atas 0,7 yang berarti peserta didik memiliki penguasaan konsep. Hasil perhitungan nilai pretest dan nilai postest ada peningkatan sebesar 0,85 dengan kategori tinggi.
\end{abstract}

Kata kunci: Implementasi; Penguatan Pendidikan Karakter

\section{PENDAHULUAN}

Berdasarkan hasil kajian dan pengalaman empiris diketahui bahwa membaca merupakan salah satu rahasia sukses peserta didik dari negara maju. Masalahnya, kebiasaan membaca peserta didik SMA di Indonesia pada umumnya dan di Papua pada khususnya belum sepenuhnya tumbuh menjadi budaya. Oleh karena itu, kebiasaan membaca harus ditumbuh kembangkan di sekolah sebagai bagian dari pendidikan di SMA. Dalam rangka membudayakan kebiasaan membaca yang lebih baik dalam 
memotivasi peserta didik, Direktorat Pembinaan SMA memprogramkan pembinaan peningkatan minat membaca peserta didik SMA melalui gerakan literasi di sekolah. Pada program tersebut, sekolah bersama dengan pemangku kepentingan lainnya memfasilitasi dan menggerakkan budaya membaca peserta didik.

Dalam pengembangan kurikulum pemerintah melalui Kementerian Pendidikan Dan Kebudayaan Republik Indonesia mencanangkan penguatan pendidikan karakter bagi semua tingkat pendidikan. Program ini dicanangkan bukan tanpa alasan. Sebab, selama ini dunia pendidikan dinilai kurang berhasil dalam mengantarkan generasi bangsa menjadi pribadi-pribadi yang bermartabat.

Dunia pendidikan dinilai hanya mampu melahirkan lulusan-lulusan yang hanya baik dari segi intelektualitas yang memadai. Banyak dari lulusan sekolah yang memiliki nilai tinggi (itu pun terkadang diperoleh dengan cara yang tidak murni), berotak cerdas, berilian, serta mampu menyelesaikan berbagai soal mata pelajaran dengan sangat tepat. Kenyataannya tidak sedikit di antara peserta didik yang cerdas itu justru tidak memiliki perilaku cerdas dan sikap yang brilian, serta kurang mempunyai mental kepribadian yang baik.

Model pendidikan selalu berkembang sesuai dengan tuntutan zaman. Hal ini memang sejalan dengan kebutuhan masyarakat yang menginginkan model pendidikan yang mampu menjawab persoalan di masyarakat. Untuk itu kehadiran kurikulum 2013 sebagai salah satu instrumen dalam meningkatkan mutu pendidikan tidak hanya diterima apa adanya. Harus ada tindak lanjut yang lebih progresif agar kurikulum 2013 tersebut bisa memberi faedah dan nilai lebih kepada penguatan pendidikan karakter. Penguatan pendidikan karakter merupakan salah satu elemen penting dalam mewujudkan pilarpilar kebangkitan bangsa.

Penguatan pendidikan karakter sebagaimana tertuang dalam Peraturan Presiden Republik Indonesia Nomor 87 Tahun 2017 adalah gerakan pendidikan di bawah tanggung jawab satuan pendidikan untuk memperkuat peserta didik melalui harmonisasi olah hati, olah rasa, olah pikir, dan olah raga dengan pelibatan dan kerja sama antara satuan pendidikan, keluarga, dan masyarakat sebagai bagian dari Gerakan Nasional Revolusi Mental (GNRM). Pendidikan karakter sebagai salah satu filter yang mampu menangkis serangan negatif globalisasi perlu dimaksimalkan fungsinya. Hal ini menjadi tugas utama guru untuk dapat mengolaborasi, mengeksplorasi, mengimplementasikan di setiap ruang pembelajaran yang diampunya sehingga bibit-bibit muda generasi bangsa mampu menyerap dan mewujudkan karakter yang diharapkan, baik di ruang pembelajaran, 
keluarga, masyarakat, agama maupun bangsa dan negara.

Pendidikan dilaksanakan untuk membentuk insan yang berkarakter, sehingga pendidikan mampu membentuk manusia yang terpelajar dengan karakter yang kuat dan berkepribadian kokoh dalam pengembangan serta pengalaman, pengabdian, pemberdayaan ilmu untuk kemaslahatan. Menyikapi hal itu, institusi sekolah dan keluarga memiliki peran yang sangat penting dalam proses pendidikan terutama dalam membentuk karakter peserta didik sehingga pendidikan tidak hanya memberikan bekal ilmu pengetahuan namun juga mampu mensukseskan kehidupan anak bangsa.

Data dari dinas Pendidikan dan Kebudayaan Kota Jayapura tahun pelajaran 2016/2017 sekolah yang sudah mengimplementasikan kurikulum 2013 mencapai $65 \%$ baik jenjang SD, SMP, SMA dan SMK. Tahun pelajaran 2017/2018 seluruh sekolah jenjang SD, SMP, SMA dan SMK di Kota Jayapura sudah mengimplementasi kurikulum 2013 ke dalam perencanaan pembelajaran, pelaksanaan pembelajaran, dan hasil pembelajaran. (http://republika.co.id) .

Dalam implementasi kurikulum penguatan pendidikan karakter pada materi ruang lingkup biologi peserta didik kelas $\mathrm{X}$ di SMA Negeri 4 Jayapura perlu dikaji lebih lanjut.

\section{METODE PENELITIAN}

Metode dalam penelitian ini adalah metode purpossive sampling dan teknik pengumpulan data yang digunakan berupa kuesioner (angket), yaitu teknik pengumpulan data yang dilakukan dengan cara memberi seperangkat pertanyaan atau pernyataan tertulis kepada responden untuk dijawabnya (Sugiyono, 2016). Selain dengan teknik tersebut, juga dilihat dari hasil belajar peserta didik. Angket digunakan untuk mengetahui pendapat dari responden tentang implementasi budaya literasi sedangkan hasil belajar menggunakan tes kognitif.

\section{Instrumen Penelitian}

Pada prinsipnya meneliti adalah melakukan pengukuran, maka harus ada alat ukur yang baik. Alat ukur dalam penelitian biasanya disebut instrumen penelitian. Instrumen penelitian adalah suatu alat yang digunakan mengukur fenomena alam maupun sosial yang diamati (Sugiyono, 2016).Penelitian yang dilaksanakan di SMA Negeri 4 Jayapura menggunakan instrumen berupa seperangkat kuesioner (daftar pertanyaan atau pernyataan) berbentuk angket berstruktur, tes hasil belajar dalam bentuk obyektif atau pilihan ganda.

\section{Angket}

Angket adalah teknik pengumpulan data yang dilakukan dengan cara memberi seperangkat pertanyaan atau pernyataan tertulis 
kepada responden untuk dijawabnya (Sugiyono, 2016). Angket merupakan teknik pengumpulan data yang efisien bila peneliti tahu dengan pasti variabel yang akan diukur dan tahu apa yang bisa diharapkan dari responden. Angket juga cocok digunakan bila jumlah responden cukup besar dan tersebar di wilayah yang luas.

Pembuatan angket dalam penelitian ini menggunakan skala Likert. Skala Likert digunakan untuk mengukur sikap, pendapat, dan persepsi seseorang atau sekelompok orang tentang fenomena sosial (Sugiyono, 2016).

\section{Tes}

Tes adalah serangkaian pertanyaan atau pernyataan latihan yang digunakan untuk mengukur keterampilan, pengetahuan, inteligensi, bakat yang dimiliki oleh individu atau kelompok
(Riduwan,2010).

Tes penelitian ini menggunakan tes hasil belajar pada ranah kognitif. Tes yang diberikan berupa tes obyektif dan uraian yang terdiri dari 20 soal pilihan ganda. Setelah pembelajaran selesai kemudian diberikan tes untuk mengetahui hasil belajar peserta didik.

Nilai hasil belajar menggunakan standar Kriteria Ketuntasan Minimal (KKM) untuk materi ruang lingkup biologi yaitu 60. Penentuan nilai KKM berdasarkan ketentuan dalam penyusunan yaitu dengan mempertimbangkan komponen intake, kompleksitas, dan daya dukung. Berdasarkan KKM tersebut dibuatlah skala Likert (Tabel 1.) sebagai berikut:

Tabel 1.Pemberian skor pada penilaian hasil belajar

\begin{tabular}{|c|c|c|c|}
\hline No. & Rentang Nilai & Skala Likert & Predikat \\
\hline 1. & $86-100$ & Amat Baik & A \\
\hline 2. & $73-85$ & Baik & B \\
\hline 3. & $60-72$ & Cukup & C \\
\hline 4. & $<60$ & Kurang & D \\
\hline
\end{tabular}

Uji Validitas dan Realibilitas Instrumen

\section{Uji Validitas}

Validitas adalah suatu ukuran yang menunjukkan tingkat kevalidan atau kesahihan suatu instrumen tes. Sebuah tes dikatakan valid apabila tes tersebut dapat tepat mengukur apa yang hendak diukur (Arikunto, 2012:80).
Untuk menguji validitas instrumen penelitian menggunakan rumus korelasi pearson product moment (r) (Riduwan, 2010) yaitu:

$$
\mathrm{r}_{\mathrm{xy}}=\frac{n \sum x y\left(\sum x\right)\left(\sum y\right)}{\sqrt{\left[\ln \sum x^{2}-\left(\sum x\right)^{2} \ln \sum y^{2}-\left(\sum y\right)^{2}\right]}}
$$

Dimana : $r_{x y}=$ Koefisien korelasi antara variabel $\mathrm{X}$ dan $\mathrm{Y}, \sum_{\mathrm{x}}=$ jumlah 
seluruh skor item, $\sum_{y}=$ jumlah seluruh

skor item, $\mathrm{n}=$ jumlah responden .

Setelah itu diuji tingkat signifikansinya dengan menggunakan rumus uji-t.

$$
\mathrm{t}_{\text {hitung }}=\frac{r \sqrt{n-2}}{\sqrt{1-r^{2}}}
$$

dimana: $t_{\text {hitung }}=$ nilai $t_{\text {hitung }}, \quad r=$ koefisien korelasi hasil $\mathrm{r}_{\text {hitung, }} \mathrm{n}=$ jumlah responden

Distribusi $\mathrm{t}_{\text {tabel }}$ untuk $\alpha=0,05$ dan derajat kebebasan $(\mathrm{dk}=\mathrm{n}-2)$.

Kaidah keputusan : Jika $t_{\text {hitung }}>t_{\text {tabel }}$ berarti valid, sebaliknya, Jika $t_{\text {hitung }}<$ $\mathrm{t}_{\text {tabel }}$ berarti tidak valid.

\section{Uji Reliabilitas}

Reliabilitas menunjukkan pada satu pengertian bahwa suatu instrumen cukup dapat dipercaya untuk digunakan sebagai alat pengumpul data karena instrumen tersebut sudah baik (Arikunto, 2012). Jika dihubungkan dengan validitas maka dikatakan bahwa instrumen yang reliabel belum tentu valid tetapi reliabilitas instrumen merupakan syarat untuk pengujian validitas instrumen (Sugiyono, 2016). Untuk mengetahui reliabilitas instrumen harus menggunakan rumus Spearman Brown. Riduwan (2010) yaitu :

$$
\begin{aligned}
& \mathrm{r}_{\mathrm{ii}}=\frac{2 r b}{1+r b} \\
& \mathrm{r}_{\mathrm{ii}}=\text { koefisien reliabilitas seluruh item } \\
& \mathrm{rb}=\text { korelasi product momen } \\
& \text { pembelajaran awal-akhir }
\end{aligned}
$$

$$
\mathrm{r}_{\mathrm{b}}=\frac{n \sum x y\left(\sum x\right)\left(\sum y\right)}{\sqrt{\left(n \sum x^{2}-\left(\sum x\right)^{2}\right\}\left(n \sum y^{2}-\left(\sum y\right)^{2}\right]}}
$$

Distribusi $\left(\mathrm{r}_{\text {tabel }}\right)$ untuk $\alpha=0,05$ dan derajat kebebasan $(\mathrm{dk}=\mathrm{n}-2)$

Kaidah keputusan :Jika $r_{i i}>r_{\text {tabel }}$ berarti reliabel, sebaliknya, Jika $r_{i i}<t_{\text {tabel }}$ berarti tidak reliabel.

\section{Teknik Analisis Data}

Dalam menjawab penelitian yang dituangkan dalam hipotesis yang diajukan maka digunakan analisis korelasi dan analisis regresi. Analisis korelasi yang digunakan dalam penelitian ini adalah korelasi Product Momen (r). Rumus yang digunakan korelasi Pearson Product Moment (Riduwan, 2010).

Langkah-langkah dalam mencari korelasi Pearson Product Moment adalah :

a. Membuat Ha dan Ho dalam bentuk kalimat.

b. Membuat Ha dan Ho model statistik,

c. Membuat tabel penolong untuk menghitung korelasi PPM.

d. Mencari $r_{\text {hitung dengan cara }}$ memasukkan angka statistik dari tabel penolong dengan rumus:

$$
\mathrm{r}_{\mathrm{b}}=\frac{n \sum x y\left(\sum x\right)\left(\sum y\right)}{\sqrt{\left[n \sum x^{2}-\left(\sum x\right)^{2} \ln \sum y^{2}-\left(\sum y\right)^{2}\right]}}
$$

Untuk interpretasi koefisien korelasi nilai $r$ ditunjuk pada Tabel 2 berikut ini: 
Tabel 2.Interpretasi koefisien korelasi nilai $\mathrm{r}$

\begin{tabular}{|c|c|}
\hline Interval Koefisien & Tingkat Hubungan \\
\hline $0,80-1,000$ & Sangat Kuat \\
$0,60-0,799$ & Kuat \\
$0,40-0,599$ & Cukup Kuat \\
$0,20-0,399$ & Rendah \\
$0,00-0,199$ & Sangat Rendah \\
\hline
\end{tabular}

e. Mencari besar kecilnya sumbangan variabel $\mathrm{x}$ dengan variabel $\mathrm{y}$ dapat ditentukan dengan rumus koefisien determinasi sebagai berikut :

$K P=r^{2} x 100 \%$

Dengan :

$\mathrm{KP}=$ Nilai koefisien determinasi

$\mathrm{r} \quad=$ Nilai koefisien korelasi

f. Menguji signifikan dengan menggunakan rumus $t_{\text {hitung, }}$ yaitu:

$\mathrm{t}_{\text {hitung }}=\frac{r \sqrt{n-2}}{1-x^{2}}$

Kaidah pengujian :

Jika $t_{\text {hitung }} \geq t_{\text {tabel }}$ maka $\mathrm{H}_{0}$ ditolak artinya signifikan.

Jika $t_{\text {hitung }} \leq t_{\text {tabel }}$ maka $\mathrm{H}_{0}$ diterima artinya tidak signifikan.

Nilai $\mathrm{t}_{\text {tabel }}$ untuk $\alpha=0,05 \mathrm{dan} \mathrm{dk}=\mathrm{n}-2$ dicari pada tabel distribusi t.

\section{HASIL DAN PEMBAHASAN}

1. Uji Validitas dan Reliabilitas Instrumen.

a. Uji Validitas Instrumen.

Valid tidaknya suatu item instrumen dapat diketahui dengan cara membandingkan indeks korelasi product moment (Pearson Correlation) dengan $\mathrm{r}$ kritis .Bila korelasi tiap faktor tersebut $r_{\text {hitung }}$ memiliki nilai lebih besar dari $r_{\text {tabel}}$, maka faktor tersebut merupakan construct yang kuat. Bila harga korelasi $\mathbf{r}_{\text {hitung }}$ lebih kecil dari $\mathrm{r}_{\text {tabelmaka dapat disimpulkan }}$ bahwa butir instrumen tersebut tidak valid.

Hasil uji analisis validitas terhadap instrumen penguatan pendidikan karakter bahwa butir pertanyaan nomor 9, 29, dan 33 dari instrumen penelitian tidak valid karena koefisien korelasinya di bawah rkritis $(0,266)$ sedangkan yang lainnya dinyatakan valid karena koefisien korelasinya di atas $r$ kritis $(0,266)$. Korelasi tertinggi memiliki koefisien 0,673 dan terendah 0,176. Dengan demikian, dari 33 butir instrumen penguatan pendidikan karakter yang dapat digunakan untuk pengukuran dalam analisis regresi ada 30 butir instrumen.

Berdasarkan hasil analisis validitas terhadap instrumen hasil belajar bahwa butir pertanyaan nomor 4, 8, 9, dan 12 dari instrumen penilaian tidak valid karena koefisien korelasinya di bawah $\mathrm{r}$ kritis $(0,266)$ sedangkan yang lainnya dinyatakan valid karena koefisien korelasinya di atas $r$ kritis $(0,266)$. Korelasi tertinggi memiliki koefisien 0,966 dan terendah 0,046. Dengan demikian, dari 20 butir instrument hasil belajar yang dapat digunakan untuk pengukuran dalam analisis regresi ada 16 
butir instrumen.

b. Uji reliabilitas instrumen penguatan pendidikan karakter.

Uji reliabilitas instrumen penguatan pendidikan karakter pada Tabel 3. menunjukkan data nilai sebagai berikut :

Tabel 3. Uji Reliabilitas Penguatan Pendidikan Karakter

\begin{tabular}{|l|l|}
\hline Cronbach's Alpha & N of Items \\
\hline 0,911 & 33 \\
\hline
\end{tabular}

Tabel 3. Reliability Statistics menginformasikan bahwa nilai Alpha Cronbach untuk item penguatan pendidikan karakter sebesar 0,911. Kriteria ini menunjukkan bahwa dalam proses pembelajaran dalan pendidikan karakter perlu memperhatikan sikap yang professional sebagai seorang tenaga pendidik. Kompetensi seorang enaga pendidik memiliki empat kompetensi yaitu 1. Profesioanal, 2. Pedogogik, 3. Kepribadian dan 4. Sosial. Berdasarkan Tabel 3 tersebut menunjukkan bahwa jika nilai korelasi sama atau lebih besar dari 0,600, maka butir-butir item tersebut reliabel. Informasi Cronbach's Alpha menunjukkan bahwa instrumen penguatan pendidikan karakter mempunyai nilai di atas 0,600. Dengan demikian, instrumen memiliki reliabilitas tinggi. Uji reliabilitas instrumen hasil belajar pada Tabel 4 . menunjukkan hasil sebagai berikut:

Tabel 4. Uji Reliabilitas Instrumen Hasil Belajar

\begin{tabular}{|l|l|}
\hline Cronbach's Alpha & N of Items \\
\hline 0,949 & 20 \\
\hline
\end{tabular}

Tabel 4. Reliability Statistics menginformasikan bahwa nilai Alpha Cronbach untuk item hasil belajar sebesar 0,949. Kriteria menyebutkan, jika nilai korelasi sama atau lebih besar dari 0,600, maka butir-butir item tersebut reliabel. Informasi Cronbach's Alphamenunjukkan bahwa instrumen hasil belajarmempunyai nilai di atas 0,600. Dengan demikian, maka instrumen hasil belajar reliabel.

Hasil Perhitungan Uji-t Penguatan Pendidikan Karakter ditunjukkan pada Tabel 5 berikut:

Tabel 5.Hasil Perhitungan Uji-t Penguatan Pendidikan Karakter

\begin{tabular}{|c|c|c|c|c|c|}
\hline \multirow[t]{2}{*}{ Model } & \multicolumn{2}{|c|}{$\begin{array}{l}\text { Unstandardized } \\
\text { Coefficients }\end{array}$} & \multirow{2}{*}{$\begin{array}{c}\text { Standardized } \\
\text { Coefficients } \\
\text { Beta }\end{array}$} & \multirow[t]{2}{*}{$\mathrm{T}$} & \multirow[t]{2}{*}{ Sig. } \\
\hline & $\mathrm{B}$ & Std. Error & & & \\
\hline (Constant) & 63.870 & 4.429 & & 14.422 & .000 \\
\hline \begin{tabular}{|l} 
Penguatan \\
Pendidikan \\
Karakter \\
\end{tabular} & .177 & .081 & .132 & 2.174 & .031 \\
\hline \begin{tabular}{|l|}
$\mathrm{t}_{\text {tabel }}$ \\
$\mathrm{R}$ \\
$\mathrm{R}$ Square \\
Adjusted $\mathrm{R}$ \\
$\mathrm{F}_{\text {hitung }}$ (F Ch \\
Sig F Chang
\end{tabular} & $\begin{array}{l}\text { quare } \\
\text { nge) }\end{array}$ & $\begin{array}{l}=1,960 \\
=0,132^{\mathrm{a}} \\
=0,017 \\
=0,014 \\
=4,726 \\
=0,031^{\mathrm{b}}\end{array}$ & & & \\
\hline
\end{tabular}


Berdasarkan Tabel 5 bahwa hasil analisis regresi linear sederhana antara pasangan data penguatan pendidikan karakter $\left(\mathrm{X}_{2}\right)$ terhadap hasil belajar $(\mathrm{Y})$, diketahui bahwa nilai $t_{\text {hitungyang diperoleh }}$ sebesar 2,174 dan nilai $t_{\text {tabel }}$ sebesar 1,960 dengan signifikansi sebesar 0,031. Dengan demikian,diperoleh $\mathrm{t}_{\text {hitung }}$ lebih besar dari $t_{\text {tabel }}(2,174>1,960)$ dan signifikansinya $0,031<0,05$. Secara parsial variabel penguatan pendidikan karakter $\left(\mathrm{X}_{2}\right)$ berpengaruh signifikan positif terhadap variabel hasil belajar(Y).Hal ini menunjukkan bahwa terjadi penolakan $\mathrm{H}_{0}$ dan penerimaan $\mathrm{H}_{\mathrm{a}}$ yang berarti terdapat pengaruh yang signifikan variabel penguatan pendidikan karakter $\left(\mathrm{X}_{2}\right)$ terhadap variabel hasil belajar (Y).

Persamaan regresi sederhana dari penguatan pendidikan karakter dapat dituliskan sebagai berikut:

$$
\begin{aligned}
& Y=a+b X_{2} \\
& Y=63,870+0,177 X_{2} .
\end{aligned}
$$

Persamaan di atas mempunyai arti bahwa jika penguatan pendidikan karakter naik satu satuan, maka hasil belajar (Y) akan naik sebesar 0,132 satuan dengan anggapan variabel yang lain konstan.

Nilai R sebesar $0,132^{\mathrm{a}}$ berarti bahwa hubungan antara variabel bebas penguatan pendidikan karakter terhadap variabel terikat yaitu hasil belajar termasuk kategori sangat rendah. Nilai determinasi (R Square) sebesar 0,017 artinya bahwa variasi berubahnya hasil belajar dipengaruhi oleh penguatan pendidikan karakter sebesar 1,70\% sedangkan sisanya sebesar 98,3\% dipengaruhi oleh variabel lain.

Pretest adalah tes yang diberikan kepada peserta didik sebelum pelajaran berlangsung untuk mengetahui sejauh mana peserta didik memahami pelajaran akan yang diberikan. Pretest bertujuan untuk mengukur kemampuan awal peserta didik terkait dengan materi pelajaran. Postest adalah tes yang diberikan kepada peserta didik pada akhir penyajian materi pelajaran. Postest bertujuan untuk mengukur kompetensi peserta didik setelah diberikan materi pelajaran.

\section{Penguatan Pendidikan Karakter Terhadap Hasil Belajar Materi Ruang Lingkup Biologi Peserta Didik Kelas XI SMA Negeri 4 Kota Jayapura.}

Variabel penguatan pendidikan karakter ternyata berpengaruh signifikan terhadap hasil belajar. Nilai $t_{\text {hitungyang }}$ diperoleh sebesar 2,174 dan nilai $t_{\text {tabel }}$ sebesar 1,960 dengan signifikansi sebesar 0,031. Nilai ini menunjukkan $t_{\text {hitung }}$ lebih besar dari $t_{\text {tabel }}(2,174>1,960)$ dan signifikansinya $0,031<0,05$. Secara parsial variabel penguatan pendidikan karakter $\left(\mathrm{X}_{2}\right)$ berpengaruh signifikan terhadap variabel hasil belajar (Y).Hal ini menunjukkan bahwa terjadi penolakan $\mathrm{H}_{0}$ 
dan penerimaan $\mathrm{H}_{\mathrm{a}}$ yang berarti terdapat pengaruh yang signifikan variabel penguatan pendidikan karakter $\left(\mathrm{X}_{2}\right)$ terhadap variabel hasil belajar (Y). Persamaan regresi sederhana $\mathrm{Y}=63,870+$ 0,177 $\mathrm{X}_{2}$ artinya bahwa jika penguatan pendidikan karakter naik satu satuan, maka hasil belajar (Y) akan naik sebesar 0,132 satuan dengan anggapan variabel yang lain konstan.

Hasil analisis korelasi antara implementasi penguatan pendidikan karakter diperoleh nilai koefisien korelasi $\mathrm{R}$ sebesar 0,132 . Nilai ini menunjukkan bahwa adanya keterkaitan antara penguatan pendidikan karakter terhadap hasil belajar sangat rendah. Dengan demikian, berarti makin baik guru menerapkan penguatan pendidikan karakter didalam penyusunan perencanaan dan pelaksanaan pembelajaran, makin baik hasil belajar peserta didik kelas XI SMA Negeri 4 Kota Jayapura.

Besarnya sumbangan atau kontribusi variabel penguatan pendidikan karakter terhadap hasil belajar materi ruang lingkup biologi dapat diketahui melalui nilai koefisien determinasi (R Square) sebesar 0,017. Hasil analisis tersebut menunjukkan bahwa kurang lebih $1,7 \%$ variasi perubahan hasil belajar ditentukan dengan pola fungsionalnya seperti ditunjukkan oleh persamaan regresi penguatan pendidikan karakter. Artinya jika seluruh guru SMA Negeri 4 Kota Jayapura di dalam penyusunan perencanaan dan pelaksanaan pembelajaran menerapkan penguatan pendidikan karakter, maka kurang lebih 1,7 \% skor variabel akan mengikuti pola persamaan regresi $\mathrm{Y}=$ $63,870+0,177 \mathrm{X}_{2}$

Dalam kurikulum 2013 sesuai dengan penelitian Teguh dan Tiurlina Siregar, (2017) bahwa proses belajar mengajar bukan hanya berorientasi pada komptensi peserta didik, namun hal terpenting dalam implementasi kurikulum 2013 adalah menitik beratkan penerapan penguatan pendidikan karakter.Penguatan pendidikan karakter yang merupakan bagian dari implementasi kurikulum 2013 telah termuat dalam Rencana Pelaksanaan Pembelajaran (RPP) diantaranya yaitu menghayati dan mengamalkan ajaran agama, jujur, peduli, bertanggung jawab, berpikir kritis, berkomunikasi, berkolaborasi, dan kreatif. Hal ini memiliki tujuan agar peserta didik tidak hanya berkompeten dalam materi pelajaran tetapi juga menitik beratkan pada karakter yang merupakan hasil dari pembiasaan yang dilakukan dalam pembelajaran.

Karakter dikembangkan melalui tahapan pengetahuan (knowing), pelaksanaan (acting), dan kebiasaan (habit). Peserta didik dikatakan memiliki karakter yang baik tidak hanya terbatas pada pengetahuannya tentang kebaikan saja. Peserta didik yang memiliki pengetahuan mengenai baik buruknya sifat, 
belum tentu mampu bertindak sesuai pengetahuannya, jika tidak terbiasa melakukan kebaikan. Diperlukan tiga komponen karakter yang baik (components of good character) yaitu:

a. moral knowing (pengetahuan tentang moral) yang meliputi kesadaran moral, pengetahuan tentang nilai-nilai moral, penentuan sudut pandang, logika moral, keberanian mengambil sikap, dan pengenalan diri.

b. moral feeling atau perasaan (penguatan emosi) tentang moral yang meliputi kesadaran akan jati diri, percaya diri, kepekaan terhadap derita orang lain, cinta kebenaran, pengendalian diri, dan kerendahan hati.

c. moral action atau perbuatan moral merupakan perbuatan atau tindakan moral yang merupakan hasil dari dua komponen karakter lainnya.

Pentingnya penguatan pendidikan karakter dalam pembelajaran adalah untuk meningkatkan mutu penyelenggaraan dan hasil belajar di sekolah yang mengarah pada pencapaian pembentukan karakter peserta didik. Dalam hal ini guru tidak hanya bertugas untuk menyampaikan materi pembelajaran, tetapi juga bertugas menanamkan nilai-nilai karakter pada peserta didik. Adapun nilai - nilai karakter yang diterapkan selama proses belajar mengajar diantaranya menghayati dan mengamalkan ajaran agama, jujur, peduli, bertanggungjawab,

berpikirkritis, berkomunikasi, berkolaborasi, dan kreatif. Penguatan pendidikan karakter dapat di integrasikan dalam mata pelajaran di sekolah, termasuk pada mata pelajaran biologi.

Hasil dari angket penguatan pendidikan karakter pada saat pelaksanaan proses belajar mengajar materi ruang lingkup biologi peserta didik menunjukkan karakter positif pada aspek menghayati dan mengamalkan ajaran agama, jujur, berpikir kritis, berkomunikasi, berkolaborasi, dan kreatif. Hal ini ditunjukkan presentasi rata-rata jawaban peserta didik dari angket memiliki hasil skala likert yang berada pada interval 3,0 $-3,5$ sebesar $93,3 \%$.

Presentasi rata-rata jawaban peserta didik pada pernyataan dari angket yang memiliki hasil skala likert yang berada pada interval 2,4 $-2,9$ sebesar $6,7 \%$. Hal ini disebabkan masih adanya permasalahan yang dihadapi guru pada hasil belajar peserta didik dan perlu mendapat perhatian diantaranya masih rendahnya sikap mandiri, masih ada diantara peserta didik yang kurang peduli antar sesama, dan kurang bertanggungjawab pada tugas-tugas yang diberikan guru.

2. Implementasi Penguatan Pendidikan Karakter Terhadap Hasil Belajar Materi Ruang Lingkup Biologi Peserta Didik Kelas XI SMA Negeri 4 Kota Jayapura.

Hasil analisis data yang telah dipaparkan di atas menunjukkan bahwa 
secara bersama-sama atau secara simultan ternyata terbukti bahwa variabel implementasi penguatan pendidikan karakter (X), pengaruh terhadaphasil belajar(Y)materi ruang lingkup biologi peserta didik kelas XI SMA Negeri 4 Kota Jayapura.

Uji signifikansi (uji t) terhadap tiaptiap variabel independen. Untuk Variabel implementasi penguatan pendidikan karakter diperoleh koefisien $t_{\text {hitung }}$ sebesar 2,032 dengan $p$-velue sebesar 0,043.

Nilai R sebesar 0,213 berarti bahwa hubungan antara variabel implementasi penguatan pendidikan karakter yaitu hasil belajartermasuk kategori sedang. Hal ini ditandai dengan nilai $\mathrm{R}$ dalam rentangan $0,20-0,399$ yaitu sebesar $21,3 \%$. Dengan demikian, berarti makin baik implementasi penguatan pendidikan karakter oleh seorang guru, makin baik hasil belajar peserta didik tersebut.

Besarnya sumbangan atau kontribusi variabel implementasi penguatan pendidikan karakter terhadap hasil belajar dapat diketahui melalui koefisien determinasi (R Square) sebesar 0,46. Hasil analisis tersebut menunjukkan bahwa kurang lebih $46 \%$ variasi perubahan hasil belajar ditentukan dengan pola hubungan fungsionalnya seperti ditunjukkan oleh persamaan regresi tersebut di atas. Artinya jika seluruh guru biologi SMA Negeri 4 Kota Jayapura mengimplementasikan penguatan pendidikan karakter terhadap hasil belajar, maka kurang lebih $46 \%$ variasi pasangan akan mengikuti pola persamaan regresi $\mathrm{Y}=-179,728+$ $4,903 X_{1}+0,172 X_{2}-0,071 X_{3}$. Nilai $p$ velue implementasi penguatan pendidikan karakter sebesar 0,043.

Hasil belajar merupakan suatu kemajuan dalam perkembangan peserta didik setelahmengikuti kegiatan belajar dalam waktu tertentu. Seluruh pengetahuan, keterampilan, kecakapan dan perilaku individu terbentuk dan berkembang melalui proses belajar. Umumnya hasil belajar dalam sekolah berbentuk pemberian nilai dari guru kepada peserta didik sebagai indikasi sejauh mana peserta didik telah menguasai materi pelajaran yang disampaikannya, biasanya hasil belajar ini dinyatakan dengan angka, huruf, atau kalimat dan terdapat dalam periode tertentu. Benjamin S. Bloom (dalam Rochmad, 2013), mengklasifikasikan hasil belajar ke dalam ke dalam tiga ranah yaitu: 1) ranah kognitif (cognitive domain);2) ranah afektif (affective domain); dan 3) ranah psikomotor (psychomotor domain).Aspek yang dominan meliputi aspek pengetahuan, praktik, dan afektif. Dengan demikian, materi ruang lingkup biologi penilaiannya mengacu pada tiga ranah hasil belajar.

Pelaksanaan pembelajaran kepada peserta didik kelas XI SMA Negeri 4 Kota Jayapura dengan penguatan 
pendidikan karakter pada materi ruang lingkup biologi yang dilaksanakan di SMA Negeri 4 Kota Jayapura ketuntasan hasil belajar mencapai 93,24\% dan sisanya 6,76 $\%$ tidak tuntas.

Ketuntasan hasil belajar materi ruang lingkup biologi peserta didik kelas XI dari setiap sekolah termasuk dalam kategori baik. Ketuntasan pada SMA Negeri SMA Negeri 4 sebesar 88,24\%, Tinggi rendahnya hasil belajar peserta didik tergantung pada banyak faktor. Faktor yang mempengaruhi proses dan hasil belajar peserta didik di sekolah di antaranya faktor internal dan eksternal. Faktor internal (faktor dari dalam diri peserta didik), meliputi keadaan kondisi jasmani (fisiologis), dan kondisi rohani (psikologis). Faktor eksternal (faktor dari luar diri peserta didik), terdiri dari faktor lingkungan, baik sosial dan non sosial dan faktor instrumental (M. Alisuf Sabri, 2010). Peningkatan Hasil Belajar Materi Ruang Lingkup Biologi Peserta Didik Kelas XI SMA Negeri 4 Kota Jayapura. Hasil pengolahan data dari hasil penilaian pretest dan postest materi ruang lingkup biologi sebagaimana pada Gambar 1 berikut:

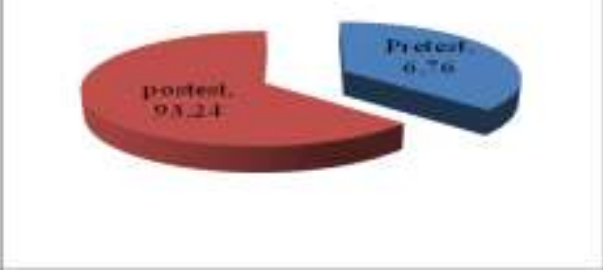

Gambar 1. Hasil Nilai Pretest dan Postest
Hasil perhitungan nilai pretest dan nilai postest peserta didik kelas XI SMA Negeri 4 Kota Jayapura ada peningkatan sebesar 0,5. Dengan demikian bahwa peningkatan penguasaan konsep materi ruang lingkup biologi peserta didik kelas XI SMA Negeri 4 Kota Jayapura berada di atas 0,7 yang berarti peserta didik memiliki penguasaan konsep. Peningkatan hasil belajar materi ruang lingkup biologi terjadi karena guru menguasai materi yang disampaikan sehingga peserta didik lebih aktif dimana interaksi antara guru meningkat secara signifikan. Hal ini disebabkan sistem penerimaan peserta didik baru (PPDB) tahun ajaran 2019/2020 merupakan sistem zonasi sekolah yaitu Peraturan Kementerian Pendidikan dn Kebudayaan (Permendikbud) Nomor 44 Tahun 2019. Sistem zonasi pada awalnya bertujuan memberikan akses pendidikan berkualitas dan mewujudkan Tripusat Pendidikan (sekolah, keluarga, masyarakat) dengan bersekolah di lingkungan tempat tinggal. Sistem zonasi ini membantu memetakan para peserta didik menuju jenjang selanjutnya. Terkait dengan hal tersebut sekolah SMA Negeri 4 Jayapura menjadi idola bagi masyarakat karena selain sistem penerimaan yang baik, model pembelajaran di kelas sudah terkordinasi dengan kepala sekolah. Hal senada dengan hasil penelitian dari Perty Mince Paembang, Tiurlina Siregar (2013) bahwa kepemimpinan kepala sekolah 
mempengaruhi kinerja guru MIPA.

\section{SIMPULAN DAN SARAN}

SIMPULAN

Terdapat pengaruh implementasi penguatan pendidikan karakter terhadap hasil belajar materi ruang lingkup biologi kelas XI SMA Negeri 4 Kota Jayapura. Hal ini berdasarkan hasil uji regresi sederhana diperoleh $t_{\text {hitung }}$ lebih besar dari $\mathrm{t}_{\text {tabel }}(2,174>1,960)$ dan signifikansinya $0,031<0,05$ dengan persamaan regresi $Y=63,870+0,177 X_{2}$ dengan sumbangan atau kontribusi relatif sebesar 1,7 \%, Peningkatan penguasaan konsep materi ruang lingkup biologi berada di atas 0,3 dan di bawah 0,7 yang berarti peserta didik memiliki penguasaan konsep. Hasil perhitungan nilai pretest dan nilai postest ada peningkatan sebesar 0,85 dengan kategori tinggi.

\section{SARAN}

Pelaksanaan pembelajaran guru hendaknya menumbuhkan penguatan pendidikan karakter peserta didik dengan menghayati dan mengamalkan ajaran agamanya, jujur, peduli, bertanggung jawab, berpikir kritis, berkomunikasi, berkolaborasi, dan kreatif.

\section{UCAPAN TERIMAKASIH}

Terimakasih kepada Program Studi S2 Magister Pendidikan IPA FKIP Uncen yang telah telah memberi bantuan dalam penelitian ini dan Kepada Sekolah SMA Negeri 4 Jayapura sebagai tempat penelitian.

\section{DAFTAR PUSTAKA}

Alisuf, Sabri, 2010, Psikologi Pendidikan, Jakarta : Pedoman Ilmu Jaya;

Arikunto, 2012. Prosedur Penelitian: Suatu Pendekatan Praktik, Jakarta: Rineke Cipta;

Pengelola MPI, 2017, Panduan Akademik Dan Penulisan Tesis, Jayapura: Magister Pendidikan IPA;

Perty Mince Paembang dan Tiurlina Siregar, 2013, Pengaruh kepemimpinan kepala sekolah, motivasi kerja dan disiplin kerja terhadap kinerja guru MIPA SMP Kabupaten Mambramo Tengah, Jurnal Ilmu Pendidikan Indonesia, Vol 1 (3) 1-9;

Peraturan Presiden ,Nomor 87, Tahun 2017, tentang ,Penguatan Pendidikan Karakter;

Peraturan Menteri Pendidikan dan Kebudayaan Republik Indonesia, Nomor 59, Tahun 2014, tentang Kurikulum 2013 sekolah Menengah Atas/Madrasah Aliyah;

Peraturan Menteri Pendidikan dan Kebudayaan Republik Indonesia, Nomor 17, Tahun 2007, tentang Standar Kualifikasi Akademik dan Kompetensi Guru;

Peraturan Pemerintah, Nomor 32, Tahun 2013, tentang Standar Nasional Pendidikan;

Peraturan Menteri Pendidikan dan Kebudayaan Republik Indonesia, Nomor 23, Tahun 2015, tentang Penumbuhan Budi Pekerti;

Peraturan Menteri Pendidikan dan Kebudayaan Republik Indonesia, Nomor 22, Tahun 2016, tentang 
Standar Proses Pendidikan Dasar dan Menengah;

Peraturan Menteri Pendidikan dan Kebudayaan Republik Indonesia, Nomor 23, Tahun 2016, tentang Standar Penilaian Pendidikan;

Riduwan, 2010, Skala Pengukuran Variabel-Variabel Penelitian, Alfabeta, Bandung;

Rochmad, Revisi Taksonomi Bloom (A Revision Of Bloom's Taxonomy), http://blog.unnes.ac.id/rochmad/files/ 2012/05/ROCHMAD

BLOOMORI.pdf, diakses tanggal 1 Januari 2013;
Sugiyono. 2016, Metode Penelitian Pendidikan, Pendekatan Kuantitatif, Kualitatif, dan $R$ \& D. Bandung: Alfabeta;

Tabloid Jubi.com. 2017, Sekolah di Kota Jayapura Mulai Terapkan Kurikulum 2013, (online). (http://www.jubi.com) Diunduh tanggal 16 September 2017;

Teguh Iman Santosa,Tiurlina Siregar, 2017, Implementasi Kurikulum 2013 Dalam Pembelajaran Kimia Kelas X SMA Se-Kota Jayapura, Jurnal Ilmu Pendidikan Indonesia, Vol 3 (2) 49-59. 